Journal of Qualitative Criminal Justice \& Criminology • 2020 | Volume 9, Issue 1

\title{
Person-Based Proactivity and Community Relations: Examining Police \\ Perspectives in Troubled Times
}

Vaughn J. Crichlow ${ }^{1}$, Ross Deuchar ${ }^{2}$, Seth Wyatt Fallik ${ }^{1}$

${ }^{1}$ Florida Atlantic University, ${ }^{2}$ University of the West of Scotland

Published on: Nov 17, 2020

DOI: $10.21428 / 88 d e 04 a 1 . b c d 06 c f 2$

License: Creative Commons Attribution 4.0 International License (CC-BY 4.0). 


\section{ABSTRACT}

Deadly encounters between police and Black men have led to public outrage and increasing scrutiny of law enforcement. In response, some law enforcement leaders have called for more proactive strategies in high-crime areas. While many have criticized oppressive examples of proactivity, such as stopquestion-and-frisk, others have suggested that proactive approaches could be more effective if tailored to the needs of racial and ethnic minority residents. In this qualitative study, we explore these issues using data collected from interviews and participant observation with police officers at a Southern Police Department located near several low-income ethnic minority neighborhoods. The aim of this study is to determine how police officers interpret person-based proactivity (Such as stopquestion-and-frisk), along with other self-initiated forms of person-based proactive approaches in times of increasing public scrutiny due to reported incidents of police violence. Participants expressed frustration regarding negative public sentiment, as well as the seeming futility of doing "good police work." Many believed that mass media ignored the positive achievements of police. Participants were also concerned that negative publicity had discouraged officers from potentially effective forms of selfinitiated proactivity. The implications for proactive policing and community-informed strategies in troubled times are discussed.

\section{Introduction}

"If we're not proactive, if we don't help ourselves, no one else is going to step up," said an official from a small town in the foothills of the Sierra Nevada Mountains. She was referring to a new strategy to fight the increasing threat of wildfires in Northern California. It was a crowdsourcing campaign called "Goat Fund Me" to raise money and bring herds of goats to city-owned land to help clear brush (see National Broadcasting Company, 2019) This story is amusing, if not clever, and it seems to have very little to do with policing. It is an example of a public official being proactive in the face of challenging environmental issues, which is also applicable to contemporary policing. Proactivity has become a defining ethos in policing as many law enforcement agencies have embraced proactive approaches to address crime and disorder in their communities (Clarke, 2006; Kelling \& Coles, 1996; Stockdale, Whitehead, \& Gresham, 1999; Wilson \& Kelling, 1982).

Although proactivity certainly has its merits, questions remain regarding the legality of aggressive, proactive strategies that often target Black residents in low-income communities (Stoud, Fine, \& Fox, 2011). These concerns have led to increased public outrage and ongoing discourse on police use of force (Mazerolle \& Wickes, 2015). It is also lamentable that while some police leaders strive to be innovative and resourceful in the midst of challenging times, many of the law enforcement actions that garner public attention are problematic and person-based in nature (i.e., one-on-one encounters between police and citizens), and involve officers behaving in a questionable manner. Reports of deadly 
encounters between police and Black men in particular, such as Michael Brown, Eric Garner, Philando Castile, Walter Scott, and George Floyd, have sparked increasing public scrutiny towards the conduct of police in Black and Brown neighborhoods. As a result of the public outrage sparked by such incidents, officers may be less inclined to engage in self-initiated, person-based forms of proactivity. This may also create a quandary for some officers who recognize the limitations of reactive approaches and prefer to employ more community-oriented proactive approaches in their day-to-day policing roles rather than aggressive person-based approaches.

In the aftermath of high-profile deadly incidents involving police and citizens, this study aims to increase knowledge of how police officers make sense of their jobs and the appropriateness of proactivity in vulnerable minority communities. This study seeks to answer the following question: How do police officers interpret and frame the appropriateness of self-initiated proactive policing in an era of increasing public scrutiny? Qualitative data were drawn from ethnographic observations, along with in-depth interviews with law enforcement personnel in a Southern Police Department (hereafter referred to as Lake Vista Police Department). Perspectives on the impact of proactive approaches on police-community relations are discussed, along with ways to encourage more community-oriented proactivity strategies to improve police legitimacy perceptions.

\section{Background}

\section{Reactivity and proactivity}

The terms "reactivity" and "proactivity" reflect contrasting notions about police work. These notions are not always contradistinctive given the fluid nature of police work and the need for police to respond to diverse people and situations, yet, they are often perceived as separate approaches. While reactive approaches entail responses to crimes after they occur, proactivity calls for police to emphasize crime prevention (Nix \& Rojek, 2014). Reactive approaches might include the rapid response to calls for service, retrospective criminal investigations, and randomized patrol. Proactive approaches, on the other hand, comprise strategies such as hot-spots and intelligence-led policing, which are primarily used to prevent crime from coming to fruition (Braga \& Weisburd, 2015).

Despite the benefits derived from technological tools to enhance law enforcement capabilities, reactive approaches reflect a traditional philosophy of policing that is ultimately ineffective in dealing with a growing crisis of confidence in law enforcement (Brunson, 2007; Walker, 1984). The need for more proactivity was heightened by rising crime rates and social unrest in the 1960 s as it became clear that reacting to crime does not significantly increase public safety in troubled neighborhoods (Walker, 1984), and it also does little to improve perceptions towards police among Black residents (Staples, 1975; Tyler, 2004). As a result, the decades following the Civil Rights Movement saw an increasing 
number of agencies using proactive approaches, and today, many police departments have incorporated proactive approaches into their repertoire (Nix \& Rojek, 2014).

Proactivity often refers to self-initiated, future-focused actions intended to bring about changes to work processes by inventing new means, negotiating new ends, and attempting to solve problems that have not yet occurred (Grant \& Ashford, 2007; Vough et al., 2017). Self-initiated forms of proactivity are often validated in social contexts that encourage proactivity (Frese \& Fay, 2001; Grant \& Ashford, 2007). Furthermore, self-initiation is an important part of the anticipatory impetus of proactivity, often with the goal of finding alternative means for providing solutions in professional settings (Grant \& Ashford, 2007). This framing of proactivity applies to the duties of police officers given the varied and dynamic demands of policing on the street and interactions with diverse residential populations, and the need to adopt strategies for preventing crime rather than simply reacting to crime. Yet, despite the best intentions of some law enforcement agencies, proactive approaches can be just as harmful as reactive policing when it comes to public sentiment, as proactive strategies can cause the public to question the legitimacy of police actions (Brunson, 2007; Tyler, 2001; 2004). Moreover, proactive crime control strategies have been criticized for their disparate impact on racial and ethnic minorities (Fagan \& Davies, 2000; Fallik, 2019; Fallik \& Novak, 2013; Sampson \& Lauritsen, 1997; Staples, 1975).

\section{Aggressive policing in minority neighborhoods}

Proactive policing approaches can be characterized in different ways and cover a range of responses that reflect the police focus on individuals, various types of crime, and problematic geographic locations (Kochel \& Weisburd, 2017). While there is evidence regarding the crime-reduction benefits of some proactive approaches, whether they be self-initiated or otherwise (Skogan \& Frydl, 2004; Weisburd \& Eck, 2004), there is growing concern that police might be encouraged to unfairly target Black and Brown people residing in disadvantaged areas under the subtext of enforcement activities in crime prone neighborhoods.

Moreover, aggressive policing may increase adverse contact with citizens during pedestrian and vehicle stops and negatively impact community perceptions (Gau \& Brunson, 2010; Kochel, 2011; Rosenbaum, 2006). Unfavorable perceptions towards police may also be heightened in jurisdictions that practice the "broken windows" philosophy, which calls for the deliberate and sustained policing of misdemeanors such as loitering, public intoxication, and turnstile jumping. This ethos of disorder reduction contends that by policing minor crimes, the police can reduce disorder, send a message that crime will not be tolerated, and achieve a decrease in serious crime in the long term (Harcourt \& Ludwig, 2006; Kelling \& Coles, 1996; Skolnick \& Bayley, 1986; Wilson \& Kelling, 1982). 
Such approaches do little to assuage public concerns regarding aggressive versions of "broken windows," often described as "zero tolerance policing," and beliefs regarding its often publicized harmful impact on community relations (Mastrof ski, Worden, \& Snipes, 1995; Taylor, 2006). Indeed, in the post-Ferguson era - the years following the controversial police-involved shooting of Michael Brown-and during a period characterized by reports of tragic incidents involving young Black men, there has been increasing discussion about community relations and the need to build trust in lowincome minority communities (Deuchar et al., 2019). Mr. Brown, an unarmed young Black man, was shot and killed on August 9, 2014, by a White police officer in Ferguson, Missouri (Auston, 2017). While the investigation that followed found that several bystanders observed Mr. Brown with his hands up, facing away from the officer, and cooperating with his commands when shots were fired (Deuchar, Fallik, \& Crichlow, 2018), the physical evidence of the incident would later refute some of the bystanders' claims. After reviewing the evidence, a Grand Jury ultimately decided not to indict the officer for any wrongdoing (DOJ, 2015), and many members of the public viewed this outcome as unjust. Michael Brown's death, and the angry demonstrations that followed, exacerbated the legitimacy crisis, and this has become a defining event in the discourse about racial injustice in America (Bonilla \& Rosa, 2015; White \& Malm, 2020).

This renewed focus on disparities in the justice system and anti-Black racism has grown in intensity in the aftermath of the killing of George Floyd On May 25, 2020. Mr. Floyd, another unarmed Black man, was killed by a White Minneapolis Police Department officer who was recorded on video by bystanders as he callously placed his knee on the back of Floyd's neck while he lay on the ground in handcuffs (Bailey, 2020). Mr. Floyd pleaded for his life, with cries of "I can't breathe," and as the footage of his horrific death went viral, it led to an emotionally charged public response as evidenced by demonstrations all across the country and expressions of solidarity with the "Black Lives Matter" movement around the world (Bailey, 2020; Deliso, 2020; Kiang \& Tsai, 2020).

Mr. Floyd's death was yet another incident in a long line of highly publicized cases of police violence against Black residents that reflected the long-standing problem of racial disparities in police encounters with residents, as well as the generational animosity between historically Black communities and their local police agencies (Deliso, 2020). While the officer who killed Mr. Floyd might not have been explicitly engaged in a proactive policing exercise, this incident is one of the frequent reminders of the typically aggressive, person-based approaches used by many officers in predominantly Black communities. Officers who try to engage in less harmful forms of self-initiated proactivity, due to their knowledge of the neighborhoods and the relationships they may have developed over time, might be less inclined to engage with residents in an era of increased public scrutiny. Officers may also fear their conduct will be captured on video, uploaded to social media platforms, and unfairly critiqued by the public (Deuchar et al., 2019; Mac Donald 2016, Morgan \&Pally 2016). 
While the questionable actions of police might be based on agency-wide policies, police encounters with citizens also comprise a nuanced package of individualized person-focused interactions that might be more reflective of the sensibilities and judgments of individual officers rather than the official policies of the departments to which they belong. Such behaviors can be predicated on individualized beliefs and suspicions about citizens as "usual suspects" (Ariza, 2014). For instance, one of the main justifications for person-focused strategies is that a small portion of the criminal population is responsible for most crimes (Braga, Kennedy, Waring, \& Piehl, 2001). This philosophy may be one of the main drivers of stop-question-and-frisk, whether it be a part of an overarching policing strategy or simply a discretionary lever that police officers decide to pull from time to time.

\section{Person-based proactivity in the post-Ferguson era}

Researchers have categorized proactive policing as place-based, problem-oriented, person-based, or community-based interventions (See the Consensus Study Report by the National Academies of Sciences, Engineering, and Medicine, 2018). - Place-based interventions cover a range of responses that call for police to focus their attention on problematic geographic locations (Kochel \& Weisburd, 2017). Problem-oriented strategies target crime-related issues that would otherwise become bigger problems in the future (Weisburd, Telep, Hinkle, \& Eck, 2010), as they identify the problem, analyze the response, and adjust the intervention over time, if needed (Clarke, 2006; Eck \& Spelman, 1987). It is noteworthy that community-focused strategies and person-based strategies, which are the focus of this study, both highlight the need to focus on individuals within a community. Still, it is unclear if used in tandem, within the context of disadvantaged communities, whether police agencies can effectively increase public safety while also building trust.

It may be a lofty and unrealistic aspiration to expect improvements in citizens' trust in certain locations, given how person-based strategies have been conceptualized and employed by police (Fradella \& White, 2017; Harris, 2017). It may also be a concern that limited resources will impact the type and scope of approaches used by police (Clarke, 2006), and in such contexts, harmful forms of person-focused actions might be favored by some officers. Furthermore, it is an ongoing concern that person-based approaches tend to undermine community-based approaches. Although communitybased strategies can potentially enhance "collective efficacy," change community members' evaluations on the legitimacy of police actions, and increase cooperation between the police and the public (NASEM, 2018), none of these goals will be fully realized if the proactive measures employed by police have a deleterious impact on public perceptions, particularly if stop-question-and-frisk (SQF) becomes the most frequently used form of proactivity.

Stop-question-and-frisk is an important part of the phenomenon of aggressive law enforcement in minority neighborhoods and police tactics in general that have received more scrutiny in the postFerguson era. It is also arguably the most controversial and obvious form of person-based proactive 
policing, due to its intrusiveness and its impact on Black urban communities in particular (Fagan, Geller, Davies, \& West, 2010). The legal authority to perform individual SQF is grounded in the landmark 1968 Supreme Court decision-Terry v. Ohio. The jurisprudence that stems from Terry v. Ohio and similar SQF cases states that police may stop a person based upon a "reasonable suspicion" that they are about to commit, are in the process of committing, or have committed a crime. The police may also conduct a frisk of the stopped citizen if there is "reasonable suspicion" that the individual is armed and/or dangerous (Fradella \& White, 2017). SQF is often viewed as a reactive approach. Traditionally, police have used it to investigate suspicious behavior related to reported crime; however, this practice can also be used for crime prevention. SQF programs, for example, often involve blanketing city areas with pedestrian stops as a way of deterring potentially violent individuals.

Stop-question-and-frisk has also been used as a preventative tool that accomplishes focused deterrence as it sends a message to potential offenders and creates a disincentive when it comes to the commission of street crimes. As noted earlier, a growing body of research suggests that police can be more effective if they target a small number of chronic offenders (Braga \& Weisburd, 2015; Kennedy, 2008), and focused deterrence, also referred to as "pulling levers" approaches, is arguably the most empirically supported person-based approach. Focused deterrence strategies incorporate salient deterrence ideas such as using law enforcement tools to increase offender risks and directly communicating incentives and disincentives to their involuntary clients (Kennedy, 2008; Weisburd \& Eck, 2018).

Although these types of approaches can result in positive crime control benefits (Braga et al., 2001; Braga et al., 2014; Braga \& Weisburd, 2015; Papachristos, Meares, \& Fagan, 2007; Tita et al., 2004), SQF has been criticized for targeting young racial minorities (Brunson, 2007; Gelman, Fagan, \& Kiss, 2007; Ridgeway, 2007; Stoud et al., 2011). African American youths perceive police order-maintenance practices in their neighborhoods to be disrespectful, unfair, and excessive (Brunson, 2007; Gau \& Brunson, 2010; Morrow, White, \& Fradella, 2017). Moreover, there was concern that the line between a sound, constitutionally approved police practice and racial profiling had become so blurred that the public received new and innovative policing approaches with skepticism and, at times, hostility (Fradella \& White, 2017; Harris, 2017).

Given the history of antagonism between police and Black citizens, it is important to consider the impact of harmful forms of proactivity and whether the increased public scrutiny resulting from reports of police violence in Black neighborhoods has shaped law enforcement perspectives on proactive policing in the post-Ferguson era. In times where police are increasingly scrutinized, and anti-police sentiment is frequently vocalized, some police officers may be disinclined to be proactive. Furthermore, commentators have debated an alleged "Ferguson effect," which is sometimes described 
as "de-policing," which can be evidenced by a lack of responsiveness on the part of the police along with a rise in crime rates.

Empirical assessments of this question have yielded mixed results. Some studies have found contextual evidence of despondency among officers (Deuchar, Fallik, \& Crichlow, 2018; Morgan \& Pally, 2016; Nix \&Wolfe, 2016), while others have found no widespread, consistent evidence of a Ferguson effect (Pyrooz et al., 2016; Rosenfeld, 2015). Despite these findings, it is a concern whether ongoing incidents of alleged police brutality impact officers' willingness to engage with citizens given the implications for public safety and police effectiveness (Wolfe \& Nix, 2016). In addition, in a social context that is influenced by viral videos on tragic encounters between police and residents, it would be useful to consider law enforcement perspectives on community engagement strategies to increase police legitimacy in these troubled times.

\section{Current study}

With these issues in mind, this study presents a qualitative assessment of police perspectives on person-based proactive strategies in the context of a growing crisis of confidence in police that has stemmed from controversial and violent police-citizen encounters. Furthermore, this research presents the analysis of data drawn from in-depth interviews with law enforcement and recorded observations in the form of field notes. While community perceptions are essential, it is also important to give voice to the experiences and perceptions of law enforcement professionals, and the paucity of ethnographic research on police attitudes and experiences (Fassin, 2013) underlines the much needed contribution of this line of inquiry. Furthermore, there is a need for research that examines how police officers interpret and frame the appropriateness of self-initiated proactive policing in an era of increasing public scrutiny, while addressing the problem of strained community relations. The following section provides a full description of the methodology.

\section{Methods}

As stated above, this study presents a qualitative assessment of police perspectives regarding selfinitiated proactivity approaches in a context of increasing public scrutiny. The study analyzes data from ethnographic observations with Lake Vista Police, along with interviews with 20 law enforcement personnel. Lake Vista comprises approximately 38,000 residents with a racial breakdown as follows: $42 \%$ Hispanic or Latino, 35\% White Alone, $18 \%$ Black, $3 \%$ Asian, and $2 \%$ comprising other races and ethnicities. The foreign-born population represents $37.38 \%$ of the population, and 54.97\% of the residents can speak languages other than English, with the largest nonEnglish language being Spanish (U.S. Census Bureau, 2017).

Lake Vista has a median household income of approximately $\$ 36,000$, which is significantly below the national median of $\$ 63,000$. The unemployment rate in Lake Vista is $7 \%$, which is $55 \%$ higher than the 
national average, and the poverty rate is $29 \%$, which is $90 \%$ higher than the national average (U.S. Census Bureau, 2017). Lake Vista has one of the highest crime rates in America. Total index crime is higher than $94 \%$ of all U.S. cities, with robberies, assaults, and thefts being the most frequently reported crimes (Federal Bureau of Investigation, 2016).

The data collection effort was ethnographic, with the researcher taking on the role of participant-asobserver. Participant observation is a useful approach for studying groups in settings that allow researchers to explore organized routines of behavior (DeWalt \& DeWalt, 2002). It often comprises qualitative interviewing and note-taking and can help build a general understanding of social phenomena with accuracy and objectivity (Kawulich, 2005; Russell, 1994). Ethnography tends to bring greater focus to first-hand assessments of a social or cultural setting through the researcher's immersion in that setting (Atkinson, Coffey, Delamont, Lofland, \& Lofland, 2001). Furthermore, these analyses consist of varied forms of data collection and present a generative approach to inquiry that positivist designs are seldom capable of providing (Case, Todd, \& Kral, 2014). Moreover, the approach used in this study opens a window to the subjectivity and "meaning-making" behind the professional routines of police and presents a "dynamic and contradictory synthesis of subjective insider and objective outsider" (Sluka \& Robben, 2012, p. 2).

The researcher was transparent with law enforcement participants regarding the goals of the study. This allowed the researcher to build rapport with the observed officers during weekly briefings, rest breaks, and surveillance shifts. After the gatekeepers within the police agencies formally granted initial access, the data were collected from observations and in-depth interviews over four months (January-April 2017) using snowball sampling with sworn officers of varying ranks. The interviews ranged from 30 minutes to an hour in length. Immediately following each field observation, the researcher typed-up, and filled-in pertinent information while the experience was still fresh. The over 40,000 words of field notes analyzed in this study presented a rich description of the approximately 75 hours of observations. Police officers were queried with semi-structured interviews, typically held in the officers' or authors' working environment but secluded from people passing by. Questions were individualized and focused on the following areas: proactive policing strategies, perceptions regarding community relations, and the context of growing public scrutiny emerging from high profile news/social media coverage of events such as those occurring in Ferguson and Baltimore.

Of the 20 sampled officers, 18 were male; two were female, 16 identified as white, and four as African Americans. The newest hire among the participants had been in service for four years and the oldest for more than 40 years. The sample included command staff, detectives, and line-level officers with a range of experience within the agency. The process of gaining access and engaging with participants was continued until data saturation was reached (Strauss \& Corbin, 1998). Thematic analysis of the data, drawn from interview transcripts and field notes, was conducted to assess law enforcement 
perspectives on various forms of perceived proactivity and explore emerging areas of concern related to police proactivity and community relations. The content of field notes and more than 130,000 words of dialogue were analyzed inductively until saturation occurred. The process of interpreting themes was done with cognizance of existing literature on proactive policing and community-oriented approaches. The following sections comprise the presentation of findings from participant observations and interviews. Pseudonyms were substituted for the names of participants and neighborhoods within Lake Vista.

\section{Findings}

\section{Police perspectives on proactivity}

Based on insights garnered from observations and interviews, police in Lake Vista seemed to favor proactive approaches but did not always feel properly equipped for effective proactivity in the community. Participants emphasized the value of being more proactive, particularly in the context of communities that have a history of crime and violence, such as neighborhoods in Lake Vista. Officers discussed the importance of planning for, and attending to immediate problems, but also embraced longer-term thinking and recognized that police need to use alternative methods for tackling violent crime. The following quote shows the researcher reflecting on the perspectives of police officers in Lake Vista and the need for more proactive thinking when policing communities of color with historically high crime rates:

"If you intervened every time you would never be done-the minute you drive off, [individuals engaging in gang-related activity] all come back. It's a never-ending battle." This makes me reflect on just how hopeless a situation it is in these neighborhoods, and why the proactive intervention and prevention work that is now taking priority is probably best. Proactive approaches are needed, rather than simply firefighting against recurring issues. $\sim$ Field Notes

This reflective discussion and observation illustrate the recurring problems that plague disadvantaged, crime-prone areas, whereby the use of hot-spots policing and crackdowns may simply lead to a negative impact on community perceptions among minority citizens (Gau \& Brunson, 2010; Kochel, 2011; Rosenbaum, 2006). During participant observation of police deployments, one officer emphasized the intentional use of a proactive unit that could be assigned to the most problematic areas of Lake Vista; however, most participants focused on the need to show personal initiative and interact with residents when patrolling the community:

Diane drives the car into the north side of the city where most of the poverty and the crime are located. "99.9\% of our problems are up here," she says. Diane explains to me that officers in the County office can be pulled anywhere - they can go to Lake Vista North or South, but in the city 
P.D., you tend to get to know the local residents in communities. "You can call the Sheriff's Office and never get the same Deputy - that's not the case with us," she explains. Field Notes

This excerpt from the field notes highlights the role and impact of officers who have intimate knowledge of problem areas in the city and being empowered to help inform the department's priorities when it comes to proactive approaches. While formal agency-wide efforts were minimal, partly due to limited resources, participants acknowledged the utility of a proactive focus in high crime neighborhoods when combined with engagement activities. Although there was a focus on participant observation, comprising in-depth interviewing and note-taking, conversations along the margins of this topic indicated that there was a general lack of insight among law enforcement participants as to the long-term impact of this approach (Braga et al., 2014):

Wherever the crime spikes lead us, or [where] the information is leading us ... [these are the] areas we will be trying to [influence] in a positive light ... We need more officers getting out there with their windows down, talking to community members, trying to build rapport, relationships, but then also reporting back to the police department with whatever information we are finding out ... [But] I think we are gonna have to wait to see ... you know, it's not an overnight type of thing. Daniel, Sergeant

There was also a lack of insight on the consequences of focusing on "crime spikes" in the absence of a broader plan for crime prevention and engagement with residents in neighboring communities.

Observations across Lake Vista indicated that policing approaches rely heavily on the use of surveillance to unearth and prospectively investigate criminal activities. One participant stated that his unit had props that could help officers remain incognito, such as "drop cars," pole cams, cigarette packs, and baseball hats - "We have a lot of good stuff that we can employ here," said John (Detective). Participants also referred to the shot-spotter program: "When someone is firing a gun around, we can pinpoint where it is within 2-3 feet, using devices tied to GPS coordinates," noted Samuel (Lieutenant). Officers felt that this led to greater efficiency in terms of faster police response times, but they bemoaned the lack of training and resources to execute evidence-based problem-oriented policing strategies:

We're just not trained enough, equipped enough. We get all these special classes, and the last class we had was on kids with autism. And Alzheimer's, right? I think they're important. And I think if you have a well-trained officer ... this is something that needs a little more attention by me and by a non-law enforcement capability. Noah, Sergeant

Similarly, the following field note highlights the perceived importance of using technology proactively, as well as inter-agency cooperation, to deal with the problems associated with illegal guns and violent 
youth gangs:

Samuel goes on to talk about the way the County department regularly coordinates with other agencies such as narcotics agencies. "The major thing is guns and gangs - we try to do everything we can to take the guns off the streets. But we need to use different investigative means-if we can use the technology to see something on the streets in plain view, then we don't need to use stop and frisk." Field Notes

There was a strong focus on problem-oriented approaches to police proactivity as a means of targeting issues that could become bigger problems (Brunson, 2007; Weisburd et al., 2010), such as gun and gang violence. However, against the constant need for upskilling officers, and the ongoing problem of limited resources, there was a lack of insight into the longer-term impact of these approaches. In fact, some officers openly articulated their pessimism, feeling that proactive, problem-solving approaches simply led to the forming of cases that were ultimately not held up in court: "We arrest them, give them a slap on the hand, and they're right back then ... the less proactive enforcement, less penalties," said Andrew (Detective). Although officers in Lake Vista were open to problem-oriented approaches, the critical sentiment of Detective Andrew was common among the sample of officers. Substantively, officers indicated that these approaches needed to be combined with overlapping enforcement strategies and a more conservative and robust judicial system to achieve the end result of crime reduction (Weisburd et al., 2010).

\section{Person-based proactivity and public scrutiny}

The person-focused approach to police proactivity has been shown to yield results in the short term, particularly in terms of crime reduction (NASEM, 2018). Some participants favored this approach, while others, when speaking of SQF, specifically believed that it was no longer supported as an investigative tool due to the shifting political climate (Deuchar, Fallik, \& Crichlow, 2018). Participants also believed that, if officers were continually discouraged from engaging in proactive person-based enforcement, which was deemed a way of focusing on high-risk repeat offenders, there would be a rise in crime. One participant discussed the constraints put on police and the scrutiny that resulted in a disinclination to pursue suspects:

You know, a drug dealer standing on the street ... I'm not saying all, but you got officers who are not gonna go out of their way. ... [There's] gonna be more shootings ... you know. Even our own polices have a huge effect on things. We have a "no pursuit" policy ... We've been up on wires and uh every time, we'll know the drugs are being delivered, and we go to make the stop, they'll flee. We can't chase. But it definitely works but, what's the key behind stop and frisk is [it's] proactive. $\sim$ Andrew, Detective 
Another participant highlighted the difficulties of policing spaces where there is a lack of trust in law enforcement (many of these spaces were predominantly black or Haitian neighborhoods), and talked about the empowerment of criminals and how public criticism impacts police use of discretion:

I've noticed that criminals are a lot more brazen. I think that has a lot to do with the fact that there's less officers that are out being proactive ... 'cause of the chance of getting themselves in trouble in a situation where they have to make a split-second decision and you know, everybody else in the public or in the media has you know, hours and days and days to go over the exact same decision that they made. Logan, Detective

There was a belief that officers might be pulling back a little after high profile incidents of police brutality against Black men, but that they would eventually revert to their training regarding necessary police work. It was also acknowledged that there is a right way to do SQF:

When you stop somebody, in order to search them, you should have a reason. It shouldn't just be arbitrary. Just stopping and frisking. I don't think the frisking part is, but you can still do the stopping unless you think there's a weapon or something like that. That's why you do it. So, I think sometimes the stop and frisk was used to circumvent the law and different things like that. $\sim$ Luke, Command Staff Member

Thus, although a growing body of evidence suggests that police can be more effective if they target a small number of chronic offenders and some evaluative outcomes suggest a link between the more coercive strategies, such as high pursuits and SQF, and short-term crime reduction (Braga \& Weisburd, 2015; NASEM, 2018), insights from interview data suggest that these person-based interventions are increasingly being discouraged and undermined. In fact, some participants felt that the more overtly proactive officers were targeted negatively by supervisors for "doing their job." Informal dialogue during rest breaks between police deployments created further insights into the despondency among officers in relation to what they regarded as the lack of support for person-based proactivity, within the context of officer-based shootings of young black men:

The three male officers (Logan, Andrew, and Jack) talk about how police have significantly lost their powers, and many cops are less proactive because of all the negative publicity and scrutiny. Jack describes one incident that took place recently where one black guy was pointing a gun at a cop on the street, and the cop shot him and killed him in self-defense. "The cop was sued for $\$ 20$ million," he concludes. He goes on to describe another incident where a white guy was pointing a gun at a cop when he got out of his car, and the officer shot him-and also got sued. $\sim$ Field Notes

Logan expanded on these issues in the interview. He felt that the legal system was now allowing the public to sue officers and departments for their proactivity. He believed that many officers had taken a 
step back and were not being proactive, and that gang members were aware of this issue and would exploit it. It was also clear that some officers were apprehensive of confronting young Black men in low-income communities for fear of being accused of racial profiling, as reflected in Sergeant Ryan's comment, "oh, you're stopping me because I'm black, you're stopping me because I'm Hispanic. Whereas reality is 'no, I stopped you because you're committing a crime' ... I think it causes hesitation, hesitation not only to make the stop but hesitation to act, you know with any kind of force." This supported wider evidence that suggests that the concept of de-policing may have become an issue in some communities on the back of highly-publicized incidents such as the shooting of young black men such as Michael Brown in Ferguson, Missouri (Deuchar et al., 2018; Mac Donald, 2016; Morgan \& Pally, 2016; Wolfe \& Nix, 2016). Logan also went on to defend the use of SQF and to describe circumstances where SQF was still appropriate:

If you can articulate the reason why you're checking out with somebody ... you're able to do surveillance on somebody and you can articulate the reason why you want to stop them or ... if you think they are committing a crime or are about to commit a crime, you have every reason to stop and check out with them. And if you pat them down for your safety ... you know. Logan, Detective

On the other hand, there was a feeling among officers that the positive achievements of police were not getting the same attention as the negative incidents, and that residents were using their phones to capture street encounters that reflected badly on the police: "So regardless if you're doing something right, from somebody else's perception, they're going to think you're doing something wrong" (Johnathan, Officer). Another perspective is that police officers could rise above the difficult circumstances and get to know their communities:

You need to take the time and you need to get out of your cars, and you need to get to know the people in your community. Maybe due to all the recent, you know, violence towards law enforcement and hatred towards law enforcement, officers are more reluctant to do that. But those are your ties, those are the people in the community. Those are the people that are going to give you information when you need it. Jack, Detective

The narratives and perspectives of officers in Lake Vista indicated that they primarily valued selfinitiated person-based proactivity within the context of controversial tactics such as SQF, high pursuit, and the use of force. However, the perceived reduction in the tools available to them due to evolving State policies combined with an emerging process of de-policing against the post-Ferguson backdrop meant that despondency had emerged among the participants (Deuchar et al., 2018). The subsequent section explores the theme of self-initiated proactivity as it relates to community-based strategies and concerns about public perceptions. 


\section{Self-initiated proactivity and community relations}

Many participants highlighted the importance of engaging with the community, showing concerns about social issues affecting families and connecting them with relevant resources:

We engage the kids, the offenders, but our main component is engaging the families, engaging like you know brothers, sisters, aunts, uncles, mom, dad, whoever is at the house and trying to work with them on what we can do to make the situation better, whether it is helping the offender maybe get a GED which is high school diploma, getting him college assistance and getting some type of subsidized employment, if the offender doesn't want the help ... our secondary way of doing it is maybe the house needs some help with child care where DCF will help, maybe the house needs some help with some other aspects, whether it is getting brother and sister in the school or something, whatever they need ... not just the offender but the offender's whole family. Daniel, Sergeant

Forman (2004) argued that community policing aims to mobilize the resources within a community, and that "[c]ommunity policing rejects the discredited "warrior" approach to policing, in which innercity communities were viewed as implacably hostile to the policing enterprise" (p. 2). The above sentiments from Daniel reflected a community-oriented focus on the need for "people-changing and environment-changing" (Mastrof ski \& Ritti, 2000, p. 184), where he and his colleagues appeared committed to collaborating with disadvantaged families and helping to address the complicated blend of social strains that can inflict them (Agnew, 2006), including a range of adverse childhood experiences (Felliti et al., 1998), to mobilize and extend their assets and prevent reoffending (Deuchar et al., 2018). In addition to the focus on adopting a social work-oriented, assets-based approach to policing, Daniel also described how members of his department volunteered to actively participate in peace walks where they combined a display of community solidarity with active attempts to re-engage young people, parents, and families. Such events were seen as increasingly important due to concerns around the country about deadly encounters between police and young minority males:

Once a month right now, we are still doing our peace walks which is basically the law enforcement gets with different people from the community ... we walk along the streets and we hand out documentation that's geared towards assisting with subsidized employment, education, different types of after school programs ... kids and cops dialogue, they try to bring in parents and community members to speak at different things like that. Daniel, Sergeant

The approaches described by Daniel were set within the context of local neighborhoods of color that had experienced high levels of gang-related feuds and shootings. He suggested that officers in his department were actively involved in building social bridges between law enforcement and the community where previous antagonism had been the norm (Lang \& Hornburg, 1998). During 
participant observation within these neighborhoods, self-motivated forms of proactivity were observed, as highlighted in the following field note:

I can see a little girl of around three years of age in a pink dress playing out on the front lawn of her house. "We need to get out here," Jennifer, the officer in the driving seat, says. I step out of the car and approach the little girl who Jennifer evidently knows well. The little girl, who is wearing a pink dress and bright red flip-flop shoes, looks up and her eyes light up. "Hey, have you been better at school?" Jennifer asks and the little girl says "yes" and she begins to tell Jennifer all about what she has been doing at school. Just at that moment, a middle-aged man of comes out of the house and I gather that this is her dad. He looks a little worn, and could be around 55-60. He is dressed in a camouflage green t-shirt, with gold chains around his neck, one of which has a crucifix on it. He shakes my hand and I introduce myself ... We start to head off and Jennifer reminds the little girl to do some good paintings for her ... and waves her goodbye. As we drive off, Jennifer explains to me that the little girl's mother is a prostitute. She refused to come off the street so eventually left the girl with the father to raise ... I can tell there is genuine affection there that has come from years of community-oriented approaches and from Jennifer genuinely knowing her neighborhood. Field Notes

Female police officers, in particular, have historically played a key role in the detection and prevention of child abuse (Jackson, 2017) and have displayed a concern for community welfare which enables coproductive police/community collaborations (Gill et al., 2014). Jennifer (above) played an active role in supporting families like the one discussed in the field notes. She potentially helped reduce the negative impact of adverse childhood experiences on young children through a somewhat pastoral role.

Tyler (2004) highlighted that the police need public support and cooperation to be effective in their order-maintenance role, and particularly benefit when they have the voluntary support and cooperation of the public. Building strong community-based relationships, using approaches such as the one used by Jennifer, may ultimately enhance police legitimacy and maximize community support in criminal investigations. In Lake Vista, there was also a strong concern among officers that police/community partnerships needed to reach out to boys and girls (Black and Hispanic children in particular) before they become involved in gangs and violence:

If you have a group of twenty kids that you're having to go out and speak to every night, if you can keep one of those kids, just one, from going down the wrong path, that's a win. That's a W[in]. You know? Owen, Detective

During another interview, one officer told a story about his interactions with a young Black man who started on the wrong path early, and his efforts to intervene: 
I did a stint, ten months, in a middle school that was heavy gang-influenced and we dealt with a kid that was starting out in a gang. He was getting his feet wet with [the gang] And, he was going down that bad path and when he starting messing up, I put a little tough love on him ... went to his house, talked to his mom. His mom's a great woman, didn't want her son following in the same path as the older brother did ... I gave her as much help as we could. After I got out of School Resource, I went in Narcotics ... started seeing his name pop up here and there ... I've always remembered his name and a year and a half ago, he was gunned down with gang violence ... You know, [he] was in the wrong spot. Joshua, Detective

The above quote illustrates how Joshua, a White officer, was actively attempting to re-direct young Black men away from gang lifestyles through collaboration with schools and families, albeit with only a short-term impact in some cases. Some research, however, suggests that race and neighborhood context can influence young males' interactions with and response to the police (Brunson \& Weitzer, 2009), and public policy often presupposes that officers should be racially representative of the neighborhoods they police in order to enhance public relations (Weitzer, 2000).

In Lake Vista, some participating Black officers noted that being viewed as "part" of the community they policed enabled them to connect with children and young people in a credible way, but that the lack of racially representative officers was a continuing problem. However, other Black officers had entirely different views. They believed that their race/ethnicity was a strong factor that prevented them from establishing legitimacy in the communities they served: "They look at me as being a traitor ... the community for the most part I guess, can't relate to me. Or they don't want to relate to me" (Johnathan, Officer). There was also a feeling of being "hated" and "loved" at the same time:

I've been called everything from uncle Tom to a fake Haitian ... even black people in the community may feel that blacks should not be in law enforcement because the pressure is there and ... we shouldn't be arresting at all, but then you have some other people who feel like we don't have enough black officers in our law enforcement or even in the communities, so ... we are hated and then we are loved. Calvin, Officer

One white officer summed up his views about the issue of race, community policing, and legitimacy when he claimed that the key to gaining young Black men's trust was how officers like him interacted with them:

As we turn in and out of various streets, Officer Daniel talks about his presence within these neighborhoods, "I mean here I am, 6 foot 8, 260 pounds, white-dealing with young black males. I tell you, I talk better to them than a lot of black officers, they'll tell you that. It's all about the relationships you build with them." Field Notes 
Solutions to crime in Lake Vista were viewed very much in terms of the need for community partnerships, the building of trust, and police legitimacy. Early intervention, pastoral approaches, and the mobilization of community strengths and assets were viewed as important, thus illustrating the apparent link between procedural justice, legitimacy, and prevention (Tyler, 2001, 2004). While some viewed ethnicity and the connection between race and neighborhood context as important, others simply viewed good communication and engagement as the key to building social bridges.

\section{Discussion}

Within the context of a growing crisis of confidence in policing, the focus of this study was to draw upon a qualitative exploration of officer perspectives on self-initiated and person-based proactive strategies. We also explored perspectives on community relations in troubled times by combining insights from semi-structured interviewing and field notes emerging from participant observation. Drawing upon the areas of proactivity defined within the extant literature, our data suggest that Lake Vista officers were willing to consider alternative proactive approaches combined with collaborative community engagement strategies. Simultaneously, officers highlighted the increasing importance of surveillance to investigate crime, using props, new tools, and technology to enhance investigative strategies.

Participants evidently viewed proactive policing as means of enabling disorder reduction and preventing more serious criminality-thus drawing on the "broken windows" thesis (Harcourt \& Ludwig, 2006; Kelling \& Coles, 1996; Skolnick \& Bayley, 1986; Wilson \& Kelling, 1982). They also viewed some of these strategies as holding the potential to enhance police legitimacy if they were shown to be effective in reducing crime, and thus avoid the public outrage, legal concerns, and external scrutiny of officer conduct often associated with SQF (Brunson, 2007; Gelman et al., 2007; Ridgeway, 2007; Stoud et al., 2011). However, there was a general hesitancy in terms of their views on the long-term impact of these approaches, particularly within a context of limited police resources. While some were optimistic about their impact, other officers offered pessimistic views and cited the need for combining these approaches with enforcement and a more robust criminal justice system that ensured that investigations led to prosecutions.

It is noteworthy that aggressive person-based forms of proactivity, such as SQF, have been criticized by scholars and advocacy groups (Fagan, Gellar, Davies, \& West, 2009). Such approaches have been the subject of legal challenges based on Fourth Amendment protections against unreasonable searches and seizures (Stoud et al., 2011). Concerns about police "crackdowns" involving sanctions, sudden increases in officer presence, and the threat of apprehension (Tilley, 2004) have been exacerbated further by deadly police-involved shootings (Buehler, 2017). News reports and viral videos on social media depicting the deaths of unarmed Black males at the hands of police have further fueled unfavorable 
perceptions towards police and declining trust in disadvantaged communities across the U.S. (Bosman \& Goldstein, 2014; Crichlow \& Fulcher, 2017; Weitzer \& Tuch, 2006).

In Lake Vista, it was evident that support for SQF and other person-focused strategies was still strong, despite the questionable evidence of their effects and concerns about the human rights implications of such tactics (Fagan et al., 2010). Despondency had emerged as a result of the withdrawal of support for such strategies, and de-policing had begun to take effect among some of the officers sampled (Deuchar et al., 2018). Insights from the data, however, suggested that more overt forms of community engagement had grown in favor among some participants through assets-based policing, mobilizing of community solidarity, and showing concern for community welfare as a means of crime prevention and enhancing police legitimacy (Cordner, 1999; Tyler, 2001). While participants mentioned several community-oriented programs, the community interventions that resonated most strongly were the self-initiated personal encounters with youth and families. Moreover, some officers had visceral responses to the racial and cultural landscapes within their jurisdictions, with some black officers being perceived as "sell-outs" and having greater challenges when interacting with young Black males. The reported responses of residents from minority communities to police officers of similar ethnic backgrounds reflected an interesting juxtaposition between contrasting roles of police.

Many of the community-oriented behaviors of officers seemed to reflect self-initiated proactive activities rather than agency-wide efforts to implement proactive programs. Some of these selfinitiated approaches were well-intentioned and aspirational in nature and seemed to draw a stark contrast to the SQF approach that others favored. Self-initiated person-based approaches were used by several participants who regularly interacted with residents as an essential part of their daily role as officers in the community. Furthermore, it was noteworthy that several proactive initiatives were supported by the department, such as peace walks, after-school clubs, and youth workshops. This highlights the importance of organizational support when it comes to creating an environment that supports proactivity. Conversely, it also became apparent during conversations with officers that most believed the news and social media largely ignored the good work done by police in the community and that this was a huge challenge to policing and a source of ongoing frustration (Deuchar, Crichlow, \& Fallik, 2019).

In regard to limitations, the generalizability of these findings should be considered. While small sample sizes are not uncommon for ethnographic studies with police agencies (Nix \& Wolfe, 2016), this research could not make strong generalizations regarding the real-world impact of proactive interventions in Lake Vista. The researchers were also not provided access to the fusion centers where intelligence-led policing activities were conducted due to security concerns and ongoing high-level investigations. This might have deprived the authors of data on critical aspects of place-based as well as problem-oriented initiatives in Lake Vista and neighboring communities. Nevertheless, it has been 
highlighted that, relative to the extant literature on the impact of proactive policing policies on crime, there has been limited fieldwork focused on exploring the potential role that racially biased behavior plays in such proactive strategies and the ways that race may shape police encounters with local citizens in communities of color.

Emerging insights from this research suggest that Black officers were sensitive to the historical impact of racially based perceptions, as they identified residents' differing responses to community-oriented approaches. While this study increased knowledge of this dynamic, further research is needed in this area to create an evidence-base for police departments to understand the potential negative or positive consequences of proactive policing and become better equipped to align police behaviors with values of equity and justice.

\section{Conclusion}

The process with which agencies assess the scope of their proactivity can be complicated with the buffet of ideas surrounding the philosophy of proactivity. Law enforcement has a difficult mandate, as many policing approaches may serve cross-purposes between liberty and order. For instance, participants believed that proactively focusing on problem places and people were an effective crime control strategy, however such strategies are often accompanied by consequences for law enforcement legitimacy. Officers often lamented citizens' resistance to person-based initiatives such as SQF. To balance these objectives, a prescription that comprises a combination of proactive approaches is likely warranted. For instance, several officers in Lake Vista embraced several community-oriented approaches that garnered perceived benefits for youth and families, to off set more antagonistic person-based activities.

Implementing the perfect cocktail of policy ingredients requires an understanding of each element's tipping points. Selected strategies may yield diminishing returns and tradeoffs when pursing or neglecting proactivity. These considerations are further complicated by budgetary and resource limitations that often tempt police administrators to compromise long-term planning for short-term outcomes. Perhaps even more concerning is that police leaders often do not have the wherewithal to make these decisions in the absence of empirical tools for gauging when ongoing strategies are undermining community trust. The next step in police proactivity scholarship certainly has a challenging but important assignment in this regard.

Public buy-in is also important to consider. The success of an integrated approach to proactivity would be dependent upon buy-in from members of the public, who are ultimately the co-producers of crimecontrol. The voices of minority residents must be a part of this process. This is of increasing concern given the public outrage elicited by reports of police violence against Black men and the ongoing conflict between police and community members in many of America's urban centers. In light of this 
challenging social context, it may be appropriate for Lake Vista, and other jurisdictions characterized by low-income minority neighborhoods, to reallocate their proactivity efforts and prioritize community-based initiatives to regain public trust. The logic behind community-oriented proactivity is that crime solutions must involve community partnerships with law enforcement. Police can also heed the voice of the community and seek to understand how they want to be engaged. To that end, framing person-based police proactivity through a procedural justice lens, in which the perceived fairness of the process is sustained as an organizational value, could have positive implications for ongoing partnerships between the police and the community.

The notion that community-oriented approaches are needed is not a novel proposition. The slow pace of localized policing reforms and the challenge of navigating America's bifurcated political landscape often frustrates the process of developing community-informed policy. Indeed, research has discussed the difficulty of introducing reform to departments that may have been engaging in widespread unconstitutional policing. In high-crime jurisdictions, in particular, that may have a history of police violence, it is suggested that person-based approaches such as SQF should be informed and evaluated by procedural justice standards. Such standards are reflected in the following questions posed by Fradella and White (2017, p. 56): "During a stop and frisk, was the citizen treated with dignity and respect? Was the citizen given an opportunity to tell his or her side of the story? Was the officer neutral and transparent? Did the officer convey trustworthy motives?"

Ultimately, regardless of what form it takes, police proactivity would have limited success if community members do not trust the police. Furthermore, it is a difficult and complex enterprise to develop a community in which there is trust between citizens and officers, and in which all individuals are investing in mutual respect and maintaining public safety. To be effective, such efforts will require a long-term commitment that should involve quality recruitment and police training, buttressed by systematic structures that hold officers accountable for misconduct (Morrow, White, \& Fradella, 2017). While many agencies have taken steps to elicit transparency and accountability by implementing the use of body-worn cameras, this by itself will not heal the wounds of broken community trust (Fallik, Deuchar, \& Crichlow, 2020). Law enforcement leaders should also be encouraged to incorporate community-informed plans tailored to the unique needs of their municipalities. Such plans must involve treating people with dignity and respect and transparency in decision-making.

\section{References}

Agnew, R. (2006). Pressured into Crime: An Overview of General Strain Theory. Los Angeles: Roxbury. Ariza, J., 2014. Police-initiated contacts: young people, ethnicity, and the "usual suspects." Policing $\mathcal{E}$ society, 24(2), 208-223. 
Atkinson, P., Coffey, A., Delamont, S., Lofland, J., \& Lofland, L. (2001). Handbook of Ethnography. Thousand Oaks, CA: Sage.

Auston, D. (2017) Prayer, protest, and police brutality: Black Muslim spiritual resistance in the Ferguson era, Transforming Anthropology, 25(1): 11-22.

Bailey, H. (2020). More details of George Floyd's death revealed in police body camera footage. The Washington Post. https://www.washingtonpost.com/national/details-of-george-floyds-death-revealedin-police-body-camera-footage/2020/08/10/6eedf752-db3c-11ea-809e-b8be57ba616e_story.html

Bosman, J., \& Goldstein, J. (2014, August 23). Timeline for a body: 4 hours in the middle of a Ferguson street. The New York Times. Retrieved from https://www.nytimes.com/2014/08/24/us/michael-browna-bodys-timeline-4-hours-on-a-ferguson-street.html

Braga, A., Kennedy, D., Waring, E., \& Piehl, A. (2001). Problem-oriented policing, deterrence, and youth violence: an evaluation of Boston's operation ceasefire. Journal of Research in Crime and Delinquency, 38(3), 195-225.

Braga, A., Papachristos, A., \& Hureau, D. (2014). The effects of hot spots policing on crime: An updated systematic review and meta-analysis. Justice Quarterly, 31(1), 633-663.

Braga, A. \& Weisburd, D. (2015). Focused deterrence and the prevention of violent gun injuries: Practice, theoretical principles, and scientific evidence. Annual Review of Public Health, 36(1), 55-68.

Braga, A., Welsh, B., \& Schnell, C. (2015). Can policing disorder reduce crime? A systematic review and meta-analysis. Journal of Research in Crime and Delinquency, 52 (4), 567-588.

Brunson, R. (2007). “Police don't like black people”: African-American young men's accumulated police experiences. Criminology \& Public Policy, 6(1), 71-101.

Brunson, R., \& Weitzer, R. (2009). Police relations with black and white youths in different urban neighborhoods. Urban Affairs Review, 44(6), 858-885.

Buehler, J. (2017). Racial/ethnic disparities in the use of lethal force by U.S. police, 2010-2014. American Journal of Public Health, 107(2), 295-297.

Case, A., Todd, N., \& Kral, M. (2014). Ethnography in community psychology: Promises and tensions. American Journal of Community Psychology, 54 (1-2), 60-71.

Clarke, C. (2006). Proactive policing: Standing on the shoulders of community-based policing. Police Practice and Research, 7(1), 3-17. 
Clarke, R., \& Weisburd, D. (1994). Diffusion of crime control benefits: Observations on the reverse of displacement. Crime Prevention Studies, 2(1), 165-84.

Cordner, G. (1999). Elements of community policing. In L. Gaines \& G. Cordner (Eds.), Policing Perspectives: An Anthology (pp. 137-149). Los Angeles: Roxbury.

Crichlow, V. \& Fulcher, C. (2017). Black men down: An assessment of experts' quotes on deadly encounters with police. Race and Social Problems, 9(3), 171-180.

Deliso, M. (2020). Timeline: The impact of George Floyd's death in Minneapolis and beyond. ABC News. https://abcnews.go.com/US/timeline-impact-george-floyds-death-minneapolis/story? id $=70999322$

Department of Justice (2015) Department of Justice Report regarding the Criminal Investigation into the Shooting Death of Michael Brown by Ferguson, Missouri Police Officer Darren Wilson. Available from: https://www.justice.gov/sites/default/files/opa/pressreleases/attachments/2015/03/04/doj_report_on_shooting_of_michael_brown_1.pdf.

Deuchar, R., Crichlow, V., \& Fallik, S. (2019). Cops in crisis?: Ethnographic insights on a new era of politicization, activism, accountability and change in transatlantic policing. Policing and Society. DOI: 10.1080/10439463.2019.1584197.

Deuchar, R., Fallik, S., \& Crichlow, V. (2018). Despondent officer narratives and the "post-Ferguson" effect: Exploring law enforcement perspectives and strategies in a Southern American State, Policing E Society, 29(9): 1042-1057.

Deuchar, R., Søgaard, T., Holligan, C., Miller, K., Bone, A., \& Borchardt, L. (2018). Social capital in Scottish and Danish neighbourhoods: Paradoxes of a police-community nexus at the front line. Journal of Scandinavian Studies in Criminology and Crime Prevention, 19(2), 187-203.

DeWalt, K., \& DeWalt, B. (2002). Participant Observation: A Guide for Fieldworkers. Walnut Creek, CA: AltaMira Press.

Eck, J. \& Spelman, W. (1987). Problem Solving: Problem-Oriented Policing in Newport News. Washington, D.C.: Police Executive Research Forum.

Fagan, J., Gellar, A., Davies, G., \& West, V. (2009). Street stops and broken windows revisited: The demography and logic of proactive policing in a safe and changing city. In S. Rice \& M. White (Eds.), Race, Ethnicity, and Policing: New and Essential Readings (pp. 259-404). New York: New York University Press. 
Fagan, J. \& Davies, G. (2000). Street stops and broken windows: Terry, race and disorder in New York City (Working Paper Group. Paper No. 01-24). New York: Columbia Law School, Public law \& Legal Theory.

Fagan, J., Geller, A., Davies, G., \& West, V. (2010). Street stops and broken windows revisited: The demography and logic of proactive policing in a safe and changing city. In S. Rice \& M. White (Eds.), Race, Ethnicity, and Policing: New and Essential Readings (pp. 309-348). New York: New York University Press.

Fallik, S. (2019). The methodological struggles of racial profiling research: A causal question that automobile stop data has yet to answer. Criminal Justice Studies, 32(1), 32-49.

Fallik, S., Deuchar, R., \& Crichlow, V. (2018). Body-worn cameras in the post-Ferguson era: An exploration of law enforcement perspectives. Journal of Police and Criminal Psychology. DOI: $10.1007 / \mathrm{s} 11896-018-9300-2$

Fallik, S. \& Novak, K. (2012). The decision to search: Is race or ethnicity important? Journal of Contemporary Criminal Justice, 28(2), 146-165.

Fallik, S., \& Novak, K. (2013). “Police Discretion and Control: Biased-Based Policing." In Bruisnma, G. \& Weisburd, D. (Eds.) Encyclopedia of Criminology and Criminal Justice. New York: Springer Verlag, 154162.

Fassin, D. (2013). Enforcing Order: An Ethnography of Urban Policing. Cambridge, England: Polity.

Felitti, V., Anda, R., Nordenberg, D., Williamson, D., Spitz, A., Edwards, V., \& Marks, J. (1998). Relationship of childhood abuse and household dysfunction to many of the leading causes of death in adults: The Adverse Childhood Experiences (ACE) Study. American Journal of Preventive Medicine, 14(4), 245-258.

Forman, J. (2004). Community policing and youth as assets. The Journal of Criminal Law and Criminology, 95(1), 1-48.

Fradella, H., \& White, M. (2017). Reforming stop-and-frisk. Western Criminology Review, 18(3), 45-64.

Frese, M., \& Fay, D. (2001). Personal initiative: An active performance concept for work in the 21st century. In B.M. Staw \& R.M. Sutton (Eds.), Research in Organizational Behavior (Vol. 23, pp. 133-187). Amsterdam: Elsevier Science.

Gau, J. \& Brunson, R. (2010). Procedural justice and order maintenance policing: A study of inner-city young men's perceptions of police legitimacy. Justice Quarterly, 27(2), 255-279. 
Gelman, A., Fagan, J., \& Kiss, A. (2007). An analysis of the New York City Police Department's “stop-andfrisk" policy in the context of claims of racial bias. Journal of the American Statistical Association, 102 (479), 813-823.

Gill, C., Weisburd, D., Telep, C., Vitter, Z., \& Bennett, T. (2014). Community-oriented policing to reduce crime, disorder and fear and increase satisfaction and legitimacy among citizens: A systematic review. Journal of Experimental Criminology, 10(4) 399-428.

Grant, A.M., \& Ashford, SJ (2008). The dynamics of proactivity at work. Research in Organizational Behavior 28(1): 3-34.

Harcourt, B., \& Ludwig, J. (2006). Broken windows: New evidence from New York City and a five-city social experiment. The University of Chicago Law Review, 73, 271-320.

Harris, D. (2017). Racial profiling. In E. Luna (Ed.), Reforming Criminal Justice: A Report of the Academy for Justice on Bridging the Gap between Scholarship and Reform, Volume 2 (pp. 117-152). Phoenix, AZ: Academy for Justice.

Jackson, L. (2017). Gender, Welfare and Surveillance in the Twentieth Century. Manchester, England: Manchester Hive.

Kawulich, B. (2005). Participant observation as a data collection method. Forum Qualitative Sozialforschung/Forum: Qualitative Social Research, 6(2). Retrieved from http://nbnresolving.de/urn:nbn:de:0114-fqs0502430.

Kiang, M., \& Tsai, A. (2020) Statements issued by academic medical institutions after George Floyd's killing by police and subsequent unrest in the United States: Cross-sectional study, MedRxiv. DOI: https://doi.org/10.1101/2020.06.22.20137844.

Kelling, G., \& Coles, C. (1996). Fixing Broken Windows: Restoring Order and Reducing Crime in our Communities. New York: Simon \& Schuster.

Kennedy, D. (2008). Deterrence and Crime Prevention. New York: Routledge.

Kochel, T. (2011). Constructing hot spots policing: Unexamined consequences for disadvantaged populations and for police legitimacy. Criminal Justice Policy Review, 22 (3), 350-374.

Kochel, T., \& Weisburd, D. (2017). Assessing community consequences of implementing hot spots policing in residential areas: Findings from a randomized field trial. Journal of Experimental Criminology; Dordrecht, 13(2), 143-170. 
Lang, R., \& Hornburg, S. (1998). What is social capital and why is it important to public policy? Housing Policy Debate, 9(1), 1-16.

Mac Donald, H. (2016). The War on Cops: How the New Attack on Law and Order Makes Everyone Less Safe. New York: Encounter Books.

Manning, P. (2010). Democratic Policing in a Changing World. Boulder, CO: Paradigm.

Mastrofski, S. \& Ritti, R. (2000). Making sense of community policing: A theory-based analysis. Police Practice and Research, 1(2), 183-210.

Mastrof ski, S., Worden, R., \& Snipes, J. (1995). Law enforcement in a time of community policing. Criminology, 33(4), 539-563.

Mazerolle, L. \& Wickes, R. (2015). Police legitimacy in community context. Journal of Contemporary Criminal Justice, 31(2), 128-131.

Morgan, S. \& Pally, J. (2016). Ferguson, Gray, and Davis: an analysis of recorded crime incidents and arrests in Baltimore City, March 2010 through December 2015. A report written for the 21st Century Cities Initiative at Johns Hopkins University. Available from:

http://socweb.soc.jhu.edu/faculty/morgan/papers/MorganPally2016.pdf

National Academies of Sciences, Engineering \& Medicine (2018). Proactive Policing: Effects on Crime and Communities. Washington, D.C.: The National Academies Press.

National Broadcasting Company (2019). Nevada City launches "goat fund me" to prevent wildfires. NBC Bay Area. Retrieved from https://www.nbcbayarea.com/news/local/Nevada-City-Launches-GoatFund-Me-to-Prevent-Wildfires-504269131.html

Nix, J., \& Rojek, J. (2014). Proactive Policing. Oxford University Press. Oxford, England.

Nix, J., \& Wolfe, S. (2016). Sensitivity to the Ferguson effect: The role of managerial organizational justice. Journal of Criminal Justice, 47, 12-20.

Papachristos, A., Meares, T., \& Fagan, J. (2007). Attention felons: Evaluating project safe neighborhoods in Chicago. Journal of Empirical Legal Studies, 4(2), 223-272.

Pyrooz, D., Decker, S., Wolfe, S. E., Shjarback, J. A. (2016). Was there a Ferguson Effect on crime rates in large U.S. cities? Journal of Criminal Justice, 46, 1-8.

Ridgeway, G. (2007). Analysis of Racial Disparities in the New York Police Department's Stop, Question, and Frisk Practices. Document No. TR-534-NYCPF. Santa Monica, CA: RAND. 
Rosenbaum, D. (2006). The limits of hot spots policing. In D. Weisburd \& A. Braga (Eds.), Police Innovation: Contrasting Perspectives (pp. 245-263). New York: Cambridge University Press.

Russell, B. (1994). Research Methods in Anthropology: Qualitative and Quantitative Approaches (2 $2^{\text {nd }}$ Ed.). Walnut Creek, CA: AltaMira Press.

Sampson, R., \& Lauritsen, J. (1997). Racial and ethnic disparities in crime and criminal justice in the United States. Crime and Justice, 21, 311-374.

Skolnick, J., \& Bayley, D. (1986). The New Blue Line. New York: Free Press.

Skogan, W. \& Frydl, K. (2004). Fairness and Effectiveness in Policing: The Evidence. Washington, D.C.: National Academies Press.

Sluka, J., \& Robben, A. (2012). Fieldwork in cultural anthropology: An introduction. In A. Robben \& J. Sluka (Eds.), Ethnographic Fieldwork: An Anthropological Reader (pp. 1-28). Malden, MA: WileyBlackwell.

Sparrow, M. (2016). Handcuffed: What holds policing back, and the keys to reform. Washington, D.C.: Brookings Institution Press.

Staples, R. (1975). White racism, black crime, and American justice: An application of the colonial model to explain crime and race. Phylon, 36(1), 14-22.

Stockdale, J., Whitehead, C., \& Gresham, P. (1999). Applying Economic Evaluation to Policing Activity. Report for the Great Britain Home Office, Policing and Reducing Crime Unit. Research, Development and Statistics Directorate. London, England: Great Britain Home Office.

Stoud, B., Fine, M., \& Fox, M. (2011). Growing Up Policed in the Age of Aggressive Policing Policies. New York: John Jay College of Criminal Justice.

Strauss, A., \& Corbin, J. (1998). Basics of Qualitative Research: Techniques and Procedures for Developing Grounded Theory. Thousand Oaks, CA: Sage.

Taylor, R. (2006). Incivilities reduction policing, zero tolerance, and the retreat from coproduction: Weak foundations and strong pressures. In D. Weisburd \& A. Braga (Eds.), Police Innovation: Contrasting Perspectives (pp. 98-116). New York: Cambridge University Press.

Tilley, N. (2004). Using crackdowns constructively in crime reduction. In R. Hopkins Burke (Ed.), Hard Cop, Soft Cop: Dilemmas and Debates in Contemporary Policing (pp. 117-134). Portland, OR: Willan Publishing. 
Tita, G., Riley, K., Ridgeway, G., Grammich, C., Abrahamse, A., \& Greenwood, P. (2004). Reducing gun violence: results from an intervention in east Los Angeles. Santa Monica, CA: RAND Corporation.

Tyler, T. (2001). Public trust and confidence in legal authorities: What do majority and minority group members want from the law and legal institutions? Behavioral Sciences $\mathcal{E}$ the Law, 19(2), 215-235.

Tyler, T. (2004). Enhancing police legitimacy. The Annals of the American Academy of Political and Social Science, 593(1), 84-99.

U.S. Census Bureau (2017). Quick facts data. Retrieved from:

https://www.census.gov/quickfacts/fact/table/US/PST045216

Vough, H. C., Bindl, U. K., \& Parker, S. K. (2017). Proactivity routines: The role of social processes in how employees self-initiate change. Human Relations, 70(10), 1191-1216.

Walker, S. (1984). "Broken windows" and fractured history: The use and misuse of history in recent police patrol analysis. Justice Quarterly, 1(1) 57-90.

Weitzer, R. \& Tuch, S. (2006). Race and Policing in America: Conflict and Reform. New York: Cambridge University Press.

Weisburd, D. (2015). The law of crime concentration and the criminology of place. Criminology, 53(1), 133-157.

Weisburd, D., \& Eck, J. (2004). What can police do to reduce crime, disorder and fear? The Annals of the American Academy of Political and Social Science, 593(1), 42-65.

Weisburd, D., Hinkle, J., Famega, C., \& Ready, J. (2011). The possible "backfire" effects of hot spots policing: An experimental assessment of impacts on legitimacy, fear and collective efficacy. Journal of Experimental Criminology, 7(4), 297-320.

Weisburd, D., Telep, C., Hinkle, J., \& Eck, J. (2010). Is problem-oriented policing effective in reducing crime and disorder? Findings from a Campbell systematic review. Criminology \& Public Policy, 9(1), 139172 .

Weitzer, R. (2000). White, black or blue cops? Race and citizen assessments of police officers. Journal of Criminal Justice, 28(4), 313-324.

White, M., \& Malm, A. (2020) Cops, Cameras \& Crisis: The Potential \& The Perils of Body-Worn Cameras. New York: New York University Press. 
Wilson, J., \& Kelling, G. (1982). Broken windows: The police and neighborhood safety. Atlantic Monthly, 249(3), 29-38.

Wolfe, S., \& Nix, J. (2016). The alleged "Ferguson Effect" and police willingness to engage in community partnership. Law and Human Behavior, 40(1), 1-10.

\section{Contributors}

Vaughn J. Crichlow is an Associate Professor in the School of Criminology and Criminal Justice, and Associate Dean in the College of Social Work and Criminal Justice at Florida Atlantic University. He received his Ph.D. in Criminal Justice from Michigan State University and holds a Law degree from the University of London. His research interests include international and cross-cultural comparisons in policing and crime prevention, police-community encounters with ethnic minorities, procedural justice and police legitimacy perceptions.

Ross Deuchar is Professor of Criminology and Criminal Justice in the School of Education and Social Sciences at the University of the West of Scotland, Affiliate Professor in the School of Criminology and Criminal Justice at Florida Atlantic University and a Fulbright Alumnus. He has published 6 authored books and numerous peer-reviewed journal articles and book chapters on his work on gangs, violence, gang desistance and the policing of gangs.

Seth W. Fallik is an Assistant Professor and Undergraduate Program Coordinator in the School of Criminology and Criminal Justice within the College of Social Work and Criminal Justice at Florida Atlantic University. Much of Dr. Fallik's research involves ongoing researcher-practitioner collaborations and he has been published in criminal justice and criminology's top journals.

\section{Footnotes}

1. This report was prepared by a committee comprised of fifteen prominent scholars, supported by the National Institute of Justice and the Laura and John Arnold Foundation. At the time of writing, this was the most robust assessment on the consequences of different forms of proactive policing. See National Academies of Sciences, Engineering \& Medicine (2018). $ヒ$ 